\title{
Analisis Wacana Politik Capres Joko Widodo dan Prabowo Subianto dalam debat Pilpres 2019
}

\author{
Yulmi Hartinah ${ }^{1}$, Filia Maya Kindi ${ }^{2}$
}

Postgraduate Indonesian Language and Literature Education, Faculty of Literature Universitas Negeri Malang, Indonesia

\begin{tabular}{l} 
Article Info \\
\hline Article history: \\
Submitted Jan 25, 2020 \\
Revised Feb 19, 2020 \\
Accepted March 18, 2020 \\
Published April 30, 2020 \\
\hline
\end{tabular}

Keywords:

Diction

Language Style

Discourse Analysis

Political Debate

\begin{abstract}
This study complements the analysis used by presidential candidates 01 and 02 in maintaining power and gaining power. Debate is chosen as the object of research because interaction occurs between the speaker and the interlocutor. This research is designed to describe the diction and language style required in the speech of the presidential candidates 01 and 02. This study uses qualitative research with discourse analysis. The data of this study are utterances delivered by presidential candidates 01 and 02 that have been transcribed into written language. The data source was in the form of a video on the presidential election debate on 17 February 2019 which was found on Kompas TV's youtube channel. This study uses data collection techniques with documentaries. This research uses the listening method with a free conversation technique. Research words, special words, antonyms, synonyms, regional diction, connotatives, and concrete diction. The use of additional language styles pleonasme, repetition, paradox, antithesis, irony, association and litotes. The results of this study enrich the understanding of speech in political discourse that has a special characteristic of the use of diction and language styles that are distinguishing from speech in other discourses.
\end{abstract}

\footnotetext{
Yulmi Hartinah ${ }^{1}$, Filia Maya Kindi ${ }^{2}$

Postgraduate Indonesian Language and Literature Education, Faculty of Literature

Universitas Negeri Malang, Indonesian

Jl. Semarang No.5, Sumbersari, Kec.Lowokwaru, Kota Malang, East Java 65145

Email: yulmi93@gmail.com/Dickys.kindi787@gmail.com
}

\section{PENDAHULUAN}

Di bidang linguistik, wacana dipandang sebagai kesatuan makna yang dilihat sebagai bangunan bahasa yang utuh. Hal ini di karenakan setiap bagian di dalam wacana itu berhubungan secara padu. Selain dibangun atas hubungan makna antarsatuan bahasa, wacana juga terikat dengan konteks. Konteks inilah yang dapat membedakan wacana yang digunakan sebagai pemakaian bahasa dalam komunikasi dengan bahasa yang bukan untuk tujuan komunikasi. Untuk itu dalam memahami wacana (naskah/teks) kita tidak dapat terlepas dari konteksnya. Sebagai satuan gramatikal tertinggi atau terbesar, wacana dibentuk dari kalimat-kalimat yang memenuhi persyaratan gramatikal dan persyaratan kewacanaan lainnya. Persyaratan gramatikal dapat dipenuhi kalau dalam wacana itu sudah terbina kekhohesifan, yaitu adanya keserasian hubungan antara unsur internal yang meliputi kata, kalimat, teks, dan konteks dengan unsur internal yang meliputi implikatur, presuposisi, referensi, inferensi, dan konteks.

Komunikasi politik sebagai studi mengenai segala macam hal dan proses politik memungkinkan terjadinya komunikasi. Pada saat yang bersamaan, studi mengenai komunikasi itu sendiri bisa dilakukan analisis terhadap segala macam proses pengolahan, penyampaian, dan penerimaan informasi. Kedekatan antara komunikasi dan politik jelas merupakan suatu hal yang terjadi dalam kehidupan sehari-hari. Kepentingan dalam mendapatkan sesuatu merupakan motivasi seseorang untuk melakukan tindakan 
komunikasi. Kepentingan tersebut akan menentukan cara ia dalam berkomunikasi. Secara umum setiap individu atau kelompok politik akan memilih media komunikasi yang efektif untuk meraih tujuan. Hal ini menjadikan semua kegiatan politisi yang dilakukan oleh pemerintah atau kekuasaan negara beserta institusi pendukung maupun yang dilakukan rakyat pada umumnya. Komunikasi politik dalam bentuk retorika, pidato, dan penyampaian pesan politik seperti halnya kampanye di ruang publik maupun dalam kelompok kecil yang terjadi di Indonesia, dapat diamati melalui berbagai aspek yang melekat dalam komunikasi politik. Dalam komunikasi politik, setiap aspek memiliki peran tersendiri, walaupun tetap memiliki hubungan secara langsung maupun tidak langsung dalam penerapannya (Putri, 2015:52).

Komunikasi politik ini ditemukan dalam kegiatan debat pemilihan calon presiden dan calon wakil presiden tahun 2019. Di dalam wacana debat terjadi interaksi antara si penutur dan mitra tutur yang menghasilakan tuturan yang dapat mencapai tujuan yang diinginkan si penutur. Debat pasangan calon presiden dan wakil presiden pada putaran pertama ini diselenggarakan pada tanggal 17 Februari 2019 dengan peserta debat dari calon presiden nomor urut 01, yaitu Joko Widodo dan calon presiden nomor urut 02, yaitu Prabowo Subianto. Pelaksanaan debat dimoderatori oleh Annisa Dasuki dan Tommy Tjokro. Debat ini terbagi menjadi enam segmen dengan mengangkat tema energi, pangan, sumber daya alam, dan lingkungan hidup

Terdapat lima penelitian yang relevan dengan penelitian ini. Pertama, penelitian yang dilakukan oleh Hardianto, dkk (2017) dengan judul Diksi dan Gaya Bahasa pada Naskah Pidato Presiden Soekarno. Hasil penelitian menunjukkan bahwa diksi yang paling banyak digunakan adalah kata abstrak dan kata konkret, sedangkan gaya bahasa yang digunakan meliputi gaya bahasa formal, gaya bahasa tidak resmi, dan gaya percakapan bahasa. Persamaan penelitian ini dengan penelitian yang dilakukan oleh Hardianto,dkk adalah sama-sama menganalisis diksi dan gaya bahasa. Letak perbedaanya terdapat dalam kajian teori yang digunakan serta objek penelitiannya. Penelitian ini menganalisis tuturan langsung sedangkan penelitian oleh Hardianto,dkk menggunakan tuturan tidak langsung (naskah/teks).

Kedua, penelitian oleh Payuyasa (2017) dengan judul artikel Analisis Wacana Kritis Model Van Dijk dalam Program Acara Mata Najwa di Metro TV. Penelitian ini menganalisis tiga permasalahan, yaitu analisis struktur makro, super struktur, dan struktur mikro. Penelitian ini menggunakan rancangan deskriptif kualitatif dengan metode observasi sebagai metode pengumpulan data. Hasil penelitian ini adalah secara struktur makro, super struktur, dan struktur mikro, wacana bisa digunakan sebagai sebuah sarana untuk pembentukan opini penutur melalui pilihan kata, susunan kalimat, dan gaya yang tepat. Persamaan penelitian ini dengan penelitian yang dilakukan oleh Payuyasa adalah samasama menggunakan kajian analisis wacana, data berupa tuturan lisan, dan menggunakan metode kualitatif deskriptif. Letak perbedaanya pada fokus penelitian dan objek penelitian.

Ketiga, penelitian yang dilakukan oleh Noverino (2015) dengan judul artikel $A$ Bathtub Of Popcorn: Kajian Analisis Wacana Kritis Buku Cerita Anak Dwi Bahasa. Penelitian ini bertujuan mengungkap konstruksi identitas karakter utama dengan menggunakan pendekatan Analisis Wacana Kritis (AWK) pada tataran analisis makro, meso dan mikro dalam cerita bergambar anak-anak dwibahasa (Indonesia - Inggris) A Bathtub of Popcorn (Satu Bak Mandi Penuh Berondong Jagung). Analisis menunjukkan bahwa meski pun buku cerita anak-anak ini dimaksudkan untuk mempromosikan gagasan keragaman sosial dan budaya, secara tidak langsung buku cerita ini membuat representasi identitas karakter utamanya secara asimetris dengan mengedepankan kontekstualisasi yang ada pada negara berbahasa Inggris (Amerika Serikat) sebagai acuan kegiatan yang seakan-akan baik untuk dilakukan oleh anak kecil perempuan Indonesia. Dalam hal penyebutan karakter utama, konstruksi identitasnya juga tidak simetris. Persamaan penelitian ini dengan 
penelitian yang dilakukan oleh Noverino adalah sama-sama menggunakan kajian analisis wacana dan menrupakan penelitian kualitatif. Letak perbedaanya terletak pada objek penelitian dan fokus penelitian.

Keempat, penelitian yang dilakukan oleh Setiarini (2015) dengan judul artikel Dongeng "The Witches' House" dan Terjemahannya "Rumah Para Penyihir": Sebuah Analisis Wacana Kritis. Pendekatan multimodalitas digunakan untuk menganalisis sebuah wacana secara kritis bukan hanya aspek linguistik, tetapi juga paralinguistik. Penelitian ini mengidentifikasi aspek-aspek linguistik dan aspek paralinguistik dalam dongeng The Witches"s House dan terjemahannya Rumah Para Penyihir. Aspek linguistik meliputi kosakata, tata bahasa dan struktur teks. Sedangkan aspek paralinguistik mencakup bentuk huruf, ukuran huruf, warna ilustrasi gambar, bentuk tubuh partisipan, dan benda-benda yang ada pada ilustrasi gambar. Peran aspek paralinguistik menguatkan karakter dan alur cerita dalam cerita dongeng ini serta menambah kedalaman ulasan linguistis. Persamaan penelitian ini dengan penelitian yang dilakukan oleh Setiarini adalah sama-sama menggunakan kajian analisis wacana. Letak perbedaanya pada objek penelitian, fokus penelitian, dan pendekatan yang digunakan.

Kelima, penelitian yang dilakukan oleh Wibowo (2015) dengan judul artikel Kajian Analisis Wacana Kritis Pada Cerita Bergambar Anak Dwi Bahasa Kura-Kura Si Penjaga Samudra (Turtle The Guard of The Ocean). Penelitian ini menyajikan kajian wacana kritis terhadap cerita bergambar bilingual Kura-Kura Si Penjaga Samudra. Investigasi kritis ini difokuskan pada kekuatan bahasa pada tataran mikro dan makro terhadap tokoh kurakura. Hasil penelitian menunjukkan bahwa penulis mencampur adukan habitat, kemampuan maupun bentuk dan istilah dalam cerita agar mempermudah anak-anak dalam mengenal hewan yang termasuk dalam ordo Chelonians ini. Karena memang untuk membedakan ketiga jenis hewan tersebut dirasa cukup sulit untuk anak kecil. Persamaan penelitian ini dengan penelitian yang dilakukan oleh Wibowo adalah sama-sama menggunakan kajian analisis wacana. Letak perbedaanya terletak pada objek penelitian dan fokus penelitian.

Penelitian ini difokuskan pada pendeskripsian diksi dan gaya bahasa dalam wacana debat pilpres tahun 2019 putaran kedua tanggal 17 Februari 2019 dengan menggunakan kajian analisis wacana. Data yang diambil dalam penelitian ini, yaitu tuturan yang disampaikan oleh calon presiden nomor urut 01 dan 02, yaitu Joko Widodo dan Prabowo Subianto. Pendeskripsian diksi dan gaya bahasa ini dilakukan untuk mengetahui macam-macam diksi dan gaya bahasa yang digunakan masing-masing paslon dalam mengungkapkan gagasan, ide, argumen, dan perasaan untuk mencapai tujuan yang diinginkannya. Teori analisis wacana yang digunakan dalam penelitian ini mengacu pada teori Zaimar dan Ayu (2015: 182-183) yang membagi diksi menjadi dua, yaitu denotasi dan konotasi, Sedangkan gaya bahasa menurut Zaimar dan Ayu (2015:184-210) ada empat, yaitu perbandingan makna, oposisi makna, pertautan makna, dan mengambil bentuk majas lain.

Penelitian ini penting untuk dilakukan karena dapat menambah wawasan dan pengetahuan bagi peneliti untuk menganalisis menggunakan kajian analisis wacana terutama terkait penggunaan diksi dan gaya bahasa dalam debat. Hasil penelitian ini dapat dijadikan referensi bagi pembaca, khususnya mahasiswa program studi Pendidikan Bahasa dan Sastra Indonesia untuk memahami diksi dan gaya bahasa dalam konteks politik dan dapat dijadikan referensi bagi guru Bahasa Indonesia dalam mengajarkan materi diksi dan gaya bahasa kepada siswa.

\section{TEORI DAN METODOLOGI}

\section{Teori}

Penelitian ini menggunakan dua teori utama, yaitu teori mengenai diksi dan teori penggunaan gaya bahasa. Pengertian pilihan kata atau diksi jauh lebih luas dari apa yang 
dipantulkan oleh hubungan kata-kata itu. Istilah ini bukan saja dipergunakan untuk menyatakan kata-kata mana yang dipakai untuk mengungkapkan suatu ide atau gagasan, tetapi juga meliputi fraseologi, gaya bahasa, dan ungkapan (Keraf, 2010: 22-23). Menurut Keraf (2010: 89-108) membagi jenis diksi menjadi sua belas. Pertama, denotasi merupakan konsep dasar yang didukung oleh suatu kata (makna itu menunjuk kepada konsep, referen atau ide). Kedua, konotasi merupakan suatu jenis makna kata yang mengandung arti tambahan, imajinasi atau nilai rasa tertentu. Konotasi merupakan kesankesan atau asosiasi-asosiasi, dan biasanya bersifat emosional yang ditimbulkan oleh sebuah kata di samping batasan kamus atau definisi utamanya. Konotasi mengacu pada makna kias atau makna bukan sebenarnya. Ketiga, kata abstrak merupakan kata yang mempunyai referen berupa konsep. Kata abstrak sulit digambarkan karena referensinya tidak dapat diserap dengan panca indra manusia. Keempat, kata konkrit merupakan kata yang menunjuk pada sesuatu yang dapat dilihat atau dirasakan oleh satu atau lebih dari pancaindra. Kata-kata konkrit menunjuk kepada barang yang aktual dan spesifik dalam pengalaman. Kata konkrit digunakan untuk menyajikan gambaran yang hidup dalam pikiran pembaca melebihi kata-kata yang lain. Kelima, kata umum merupakan kata yang mempunyai cakupan ruang lingkup yang luas. Kata-kata umum menunjuk kepada banyak hal, kepada himpunan, dan kepada keseluruhan. Keenam, kata khusus merupakan katakata yang mengacu kepada pengarahan-pengarahan yang khusus dan konkrit. Kata khusus memperlihatkan kepada objek yang khusus. Ketujuh, kata ilmiah adalah kata yang dipakai oleh kaum terpelajar, terutama dalam tulisan-tulisan ilmiah. Kedelapan, kata populer merupakan kata-kata yang umum dipakai oleh semua lapisan masyarakat, baik oleh kaum terpelajar atau oleh orang kebanyakan. Kesembilan, jargon merupakan kata-kata teknis atau rahasia dalam suatu bidang ilmu tertentu, dalam bidang seni, perdagangan, kumpulan rahasia, atau kelompok-kelompok khusus lainnya. Kesepuluh, kata slang adalah kata-kata non standard yang informal, yang disusun secara khas, bertenaga dan jenaka yang dipakai dalam percakapan, kata slang juga merupakan kata-kata yang tinggi atau murni. Kesebelas, kata asing merupakan unsur-unsur yang berasal dari bahasa asing yang masih dipertahankan bentuk aslinya karena belum menyatu dengan bahasa aslinya. Kedua belas, kata serapan adalah kata dari bahasa asing yang telah disesuaikan dengan wujud atau struktur bahasa Indonesia. Gaya bahasa merupakan bentuk retorik yaitu penggunaan kata-kata dalam berbicara maupun menulis untuk mempengaruhi pembaca atau pendengar. Dalam kaitannya dengan gaya bahasa yang berlaku di Indonesia, gaya bahasa dapat ditinjau dari bermacam-macam sudut pandang. Tarigan, (2009: 5-6) membedakan gaya bahasa menjadi empat, yaitu (1) gaya bahasa perbandingan meliputi perumpamaan, metafora, personifikasi, depersonifikasi, antitesis, dll. (2) gaya bahasa pertentangan meliputi hiperbola, litoles, ironi satire, dll. (3) gaya bahasa pertautan meliputi metonimia, alusio, alusi, dll. (4) gaya bahasa perulangan meliputi asonansi, simploke, anterasi dll.

\section{Metode Penelitian}

Metode penelitian yang digunakan dalam penelitian ini adalah metode deskriptif. Alasan peneliti menggunakan metode deskriptif karena penelitian ini bertujuan untuk memaparkan data apa adanya tanpa rekayasa dan mengungkapkan penjelasan tentang penggunaan diksi dan gaya bahasa dalam debat pilpres putaran kedua tahun 2019. Metode deskriptif merupakan metode penelitian yang mengumpulkan data-data yang berupa fakta-fakta gambaran dan bukan angka-angka sehingga laporan hasil penelitian berisi kutipan-kutipan data untuk memberikan gambaran penyajian laporan tersebut (Meleong, 2014:11). Penelitian ini bermaksud memberikan gambaran dan mendeskripsikan tuturan-tuturan yang berbentuk kata, frasa, atau kalimat yang mengandung diksi dan gaya bahasa.

Penelitian ini menggunakan pendekatan kualitatif. Penelitian kualitatif merupakan penelitian yang menggunakan latar ilmiah, dengan maksud menafsirkan fenomena yang 
terjadi dan dilakukan dengan melibatkan berbagai metode yang ada. Menurut Bogdan dan Tailor (dalam Moleong, 2014:4) metode kualitatif merupakan langkah-langkah penelitian yang menghasilkan data berupa kata tertulis atau lisan dan orang-orang dan perilaku yang dapat di amati. Dengan demikian, penelitian penggunaan diksi dan gaya bahasa dalam debat pilpres putaran kedua tahun 2019 pada akhirnya akan menghasilkan data yang bersifat deskriptif berupa kalimat-kalimat yang terdapat dalam debat tersebut.

Data dalam penelitian ini berupa tuturan calon presiden nomor urut 01 dan 02 , yaitu Joko Widodo dan Prabowo Subianto yang terdapat dalam video debat pilpres 2019 yang telah ditranskripsikan ke dalam bahasa tulis. Sumber data dalam penelitian ini adalah video debat pilpres 2019 yang diunduh melalui youtube channel Kompas TV. Debat kedua Pemilihan Presiden (Pilpres) 2019 berlangsung pada Minggu, 17 Februari 2019. Pada debat kedua ini, peserta adalah calon presiden (capres) dari kedua kubu. Debat kedua Pilpres 2019 akan diselenggarakan di Hotel Sultan, Jakarta. Tema debat kali ini adalah energi dan pangan, SDA dan lingkungan hidup, serta infrastruktur

Adapun alat pengumpul data yang digunakan, yaitu alat rekam berupa video yang didapatkan dari youtube dan tabel pencatat data untuk memudahkan peneliti dalam mengidentifikasikan, mengamati konteks tuturan, dan melakukan pencatatan. Penelitian ini menggunakan teknik pengumpulan data dengan dokumenter. Hasil dokumentasi yang berupa video debat digunakan sebagai pengamatan dan pencatatan secara sistematik terhadap gejala yang nampak pada penelitian. Teknik dokumentasi ini dipergunakan untuk mengindentifikasikan penggunaan diksi dan gaya bahasa dalam debat tersebut. Proses pengumpulan data tidak secara langsung mengamati peristiwa tutur melainkan melalui rekaman yang terdapat dalam video debat. Teknik ini biasa digunakan bila data penelitiannya adalah data tertulis atau dokumen (Muhammad, 2011:208). Penelitian ini menggunakan metode simak dengan teknik simak bebas cakap. Metode tersebut dilakukan dengan cara mengamati atau menyimak sehingga tidak ikut serta atau angkat bicara sama sekali dengan mitra tutur.

Adapun langkah-langkah yang dilakukan untuk mengumpulkan data, yaitu (1) mengamati secara intensif video debat Pilpres 2019, (2) mentranskripsikan semua tuturan dalam debat ke dalam bahasa tulis, (3) mengumpulkan data dalam transkrip yang termasuk sehingga hasil data yang telah dikumpulkan dapat tersusun secara sistematis dan sesuai dengan masalah yang terdapat dalam penelitian ini, (4) membandingkan setiap data tuturan yang terdapat diksi dan gaya bahasanya, kemudian mengelompokkannya sesuai teori yang digunakan, dan (5) pada tahap ini juga akan dilakukan kegiatan pencatatan berdasarkan urutan durasi dalam debat.

Menurut Mahsun (2013:117) tahapan analisis data merupakan tahapan yang sangat penting karena pada tahapan ini kaidah-kaidah yang mengatur keberadaan objek penelitian harus sudah diperoleh. Hal ini dikarenakan penemuan kaidah-kaidah tersebut merupakan inti dari sebuah aktivitas ilmiah yang disebut penelitian. Teknik analisis data yang dilakukan memiliki dua langkah yaitu, (1) diksi dianalisis menggunakan pendekatan linguistik struktural dan (2) gaya bahasa dianalisis menggunakan pendekatan semantis pragmatik dengan cara menentukan tuturannya, memunculkan penanda atau konteks, dan melakukan pemaknaan sebagai simpulan.

\section{HASIL DAN PEMBAHASAN}

Hasil penelitian menunjukan bahwa analisis wacana politik yang terdapat dalam debat pilpres tahun 2019 putaran kedua menggunakan berbagai diksi dan gaya bahasa. Berikut akan dipaparkan tabel hasil temuan dalam penelitian ini. 
Tabel Hasil Temuan

\begin{tabular}{ccc}
\hline Kode Data & Diksi & Gaya Bahasa \\
\hline PSI & Kata pengindraan & Pleonasme \\
PS2 & Kata khusus & Repetisi \\
PS3 \& JW4 & Kata istilah asing & Paradoks \\
JW 5 & Kata antonim & Antitesis \\
PS6 & Kata sinonim & Ironi \\
PS 7 & Diksi kedaerahan & Sinisme \\
JW8 & Diksi konotatif & Asosiasi \\
JW9 & Diksi konotatif & Perumpamaan \\
JW 10 & Diksi konkret & Litoles \\
\hline Total & 9 & 9 \\
\hline
\end{tabular}

\section{Pembahasan Penggunaan Diksi}

Menurut Keraf (2010:23) diksi atau pilihan kata dipergunakan untuk menyatakan kata-kata mana yang dipakai untuk mengungkapkan suatu gagasan, tetapi juga meliputi persoalan fraselogi, gaya bahasa, dan ungkapan. Analisis penggunaan diksi ini secara keseluruhan dapat di pahami bahwa di dalam wacana debat politik pilpres 2019 putaran kedua lebih banyak menggunakan diksi dengan makna konotasi di bandingkan diksi dengan makna denotasi. Diksi konotatif adalah penggunaan kata bermakna bukan sebenarnya. Diksi konotatif mengandung makna tambahan yang melibatkan perasaan dan emosi di dalamnya. Sedangkan, Diksi denotatif adalah pilihan kata yang bermakna sebenarnya. Diksi denotatif tidak mengandung makna tambahan (Budiarti, dkk, 2016:3). Hal ini dikarenakan di dalam komunikasi politik khususnya dalam debat tujuan yang hendak dicapai politisi adalah membujuk pendengar atau warga masyarakat untuk percaya pada validitas dari klaim-klaim si politisi. Salah satu cara untuk mecapai tujuan ini adalah dengan menggunakan pilihan kata yang mengandung makna konotasi. Permatasari (2019) menyatakan bahwa bentuk diksi merupakan bentuk pilihan kata yang mencakup penjelasan kata-kata mana yang digunakan untuk menyampaikan suatu gagasan dan ungkapan yang tepat untuk digunakan. Serta untuk membedakan kemampuan dari setiap nuansa-nuansa makna dari gagasan yang disampaikan dan kemampuan untuk menemukan bentuk diksi yang sesuai dengan situasi dan nilai rasa yang dimiliki oleh kelompok masyarakat yang mendengar. Hal ini dilakukan agar pendengar bisa memahami sendiri asumsi-asumsi dibalik informasi tanpa harus mengungkapkan asumsi tersebut secara eksplisit. Analisis penggunaan diksi ini sebagai berikut.

\section{Prabowo: "Kami yakin Indonesia bisa berdiri di atas kaki kita sendiri." (PS1)}

Kata berdiri dan kaki pada data di atas dalam diksi termasuk pemakaian kata pengindraan, yaitu indra gerak. Penggunaan kata-kata tersebut bertujuan untuk meyakinkan masyarakat Indonesia. Diksi tersebut sebagai bentuk memengaruhi masyarakat agar percaya bahwa dengan strategi yang mereka usung akan mengantarkan negara Indonesia menjadi lebih kuat dan maju. Hal ini diperkuat oleh Latifah, dkk (2016:94) yang menganalisis kalimat "Hal ini dikarenakan warga mencium bau busuk yang menyengat dari jenazah korban." Pada kalimat di atas jelas terdapat kata indria, yakni indera pembau atau penciuman. Keterlibatan indera pembau jelas ditunjukkan penulis 
pada bagian "mencium bau busuk yang menyengat" karena seperti yang kita tahu bahwa hidung berfungsi untuk membaui aroma atau bau.

Prabowo: "Kita akan menjaga pundi-pundi bangsa Indonesia supaya kekayaan kita tidak mengalir ke luar negeri." (PS2)

Kata pundi-pundi pada data (PS2) dalam diksi termasuk pemakaian kata khusus. Kata khusus adalah kata-kata yang ruang lingkup dan cakupan maknanya lebih sempit. Kata pundi-pundi merupakan kata khusus dari kantong atau tempat penyimpanan uang. Maksud dari kata pundi-pundi dari data di atas ini diartikan sebagai aset-aset yang dimiliki oleh bangsa Indonesia. Harmoko (2014) menyatakan bahwa kata khusus adalah kata-kata yang mengacu kepada pengarahan yang khusus dan konkret. Kata khusus memperlihatkan kepada objek khusus seperti Yamaha, nokia, kerapu, kakak kuta, sedan, dan sebagainya. Hal ini diperkuat oleh Reskian (2018) yang menyatakan bahwa kata khusus lebih tepat menggambarkan sesuatu daripada kata umum. Contoh analasis data dalam penelitiannya adalah kalimat "Pada tanggal 2 Januari 2018 saya dan teman-teman saya berangkat ke Pantai Enu". Kata Pantai Enu merupakan kata khusus yang tidak akan menimbulkan salah interpretasi pada pembaca. Pembaca telah memberikan gambaran secara khusus kepada pembaca agar mengetahui tempat yang dituju.

Prabowo: "Banyak infrastruktur yang dikerjakan dilaksanakan dengan grusak grusuk tanpa feasibilities study." (PS3)

Jokowi: "Dalam empat tahun ini kita telah mengejar tujuh ribu kapal-kapal asing, illegal fishing, yang melakukan illegal fishing, yang melakukan pencurian ikan di perairan kita." (JW4)

Kata feasibilities study dan illegal fishing merupakan kata yang berasal dari istilah asing. Menurut Suryawan (2013:14) menyatakan bahwa pemakaian kata atau istilah asing adalah kata-kata atau istilah asing yang sudah ada padanannya dalam bahasa Indonesia, bukan asingnya. Memakai kata-kata atau istilah asing yang hanya bermaksud megah atau gagah akan merugikan perkembangan bahasa Indonesia. Kata feasibilities study apabila diterjemahkan ke dalam bahasa Indonesia bearti studi kelayakan bisnis. Sedangkan kata illegal fishing jika diterjemahkan ke dalam bahasa Indonesia bearti penangkapan ikan ilegal. Dalam komunikasi politik, penggunaan kata asing ini bertujuan agar masyarakat mengagap si politisi memiliki pengetahuan yang kaya akan istilah-istilah asing. Hal ini akan menimbulkan penilaian yang lebih dari masyarakat kepada si politisi itu sendiri.

\section{Jokowi: "Karena apa tidak ada ganti rugi yang ada ganti untung." (JW5)}

Kata ganti rugi dan ganti untung pada data di atas menggunakan pemakaian kata antonim atau lawan kata. Kata ganti rugi bearti hasil yang didapatkan kurang, sedangakan kata ganti untung bearti hasil yang didapatkan lebih besar. Menurut Reskian (2018) antonim merupakan dua buah kata yang maknanya berlawanan. Contohnya kaya dan miskin, jantan dan betina. 
Prabowo: "Di banyak tempat selama puluhan tahun perusahaan-perusahaan besar justru melanggar meninggalkan limbah tidak mau bayar pajak yang sebenarnya untuk bersihkan limbah dan kongkalikong patgulipat dengan pejabat-pejabat." (PS6)

Kata kongkalikong dan patgulipat pada data di atas menggunakan pemakaian kata sinonim atau persamaan kata. Kata kongkalikong bearti tidak jujur, tidak terang-terangan, atau sembunyi-sembunyi. Sedangkan, kata patgulipat bearti curang, sembunyi-sebunyi. Menurut Latifah, dkk (2016:95) kata bersinonim berarti kata yang sejenis, sepadan, sejajar, serumpun dan memiliki arti yang sama. Meskipun demikian, beberapa ahli bahasa berpendapat bahwa sebagian kata-kata bersinonim dapat saling menggantikan. Misalnya, kata bocah dan kata anak bersinonim. Keduanya memiliki nuansa makna dan pengertian yang sama, sehingga bisa saling menggantikan.

Prabowo: "Kemudian juga izin-izin akan kita perketat, amdal harus dilaksanakan tidak ada jalan-jalan pintas untuk amdal yang sangat cepat sering secara legal ada tadi, tapi kadang kadang itu etok-etok." (PS7)

Kata etok-etok pada data di atas merupakan diksi kedaerahan. Penggunaan diksi kedaerahan dari bahasa Jawa berfungsi untuk mendekatkan pembicara pada pendengarnya yang memiliki latar belakang suku Jawa dan memahami bahasa Jawa. Gagasan-gagasan tertentu dapat lebih mudah dipahami dan dimengerti pesannya jika disampaikan dengan diksi kedaerahan (Agustin, 2008:7). Kata etok-etok ini berasal dari bahasa Jawa. Kata etok-etok ini dalam tafsir Jawa mengandung makna berpura-pura atau bersandiwara. Kata ini memiliki arti yang mungkin diharapkan mampu menohok lawannya dengan halus.

Jokowi: "Bukan untuk yang gede gede, bukan untukyang gede gede." (JW8)

Jokowi: "Memang tidak mungkin kita membalikkan tangan dalam sehari dua hari atau setahun dua tahun, memerlukan sebuah waktu panjang untuk melakukan itu." (JW9)

Kata gede-gede pada data di atas termasuk ke dalam diksi konotatif. Menurut Nurfadilah (2017:4) menyatakan bahwa diksi konotatif adalah makna yang sudah mendapat tambahan. Awalanya adalah makna konseptual, namun setelah mendapatkan tambahan-tambahan tertentu menjadi diksi konotatif. Diksi konotatif juga dinilai memiliki nilai komunikatif yang lebih daripada makna konseptual. Kata gede-gede menimbulkan interpretasi yang berbeda dari makna yang sebenarnya. Kata gede dalam arti yang sebenarnya adalah besar. Sedangkan kata gede dalam konteks kalimat ini diartikan sebagai kelompok-kelompok orang yang tergolong kelas ekonomi tinggi. Kemudian untuk kata membalikkan telapak tangan juga menimbulkan interpretasi yang berbeda dari makna yang sebenarnya. Dalam konteks ini membalikkan telapak tangan diartikan untuk mengatasi permasalahan yang ada tidaklah mudah dan memerlukan waktu yang lama. Hal ini diperkuat oleh Wilianti, dkk (2018:291) yang menyatakan makna konotatif adalah makna kata yang bukan sebenarnya biasanya berupa sindiran, seperti pada kalimat 'robohnya tiang penyangga hukum' kata 'tiang' bukan sebuah bangunan melainkan 
peraturan-peraturan yang dijunjung tinggi oleh suatu Negara kini tidak lagi diperdulikan sehingga masyarakat tidak takut untuk berbuat kesalahan.

Jokowi: "Kita ini manusia biasa, ada yang sudah kita kerjakan ada juga belum kita ke kerjakan karena negara ini dan negara besar bukan negara kecil." (JW10)

Kata manusia pada data di atas termasuk ke dalam diksi konkret. Dikatakan diksi konkret karena rujukan yang dimiliki kata tersebut berupa objek yang dapat diamati atau diserap oleh pancaindra manusia. Sebagai diksi konkret, kata tersebut menyajikan informasi dengan tepat kepada pendengar sehingga tidak mungkin menimbulkan salah paham (Agustin, 2008:14). Kata konkret adalah kata yang acuannya nyata atau dapat dicerap oleh pancaindera. Hal ini juga sependapat Harmoko (2014) menyatakan bahwa kata-kata konkret menunjuk kepada barang yang actual dan spesifik dalam pengalaman serta kata konkret digunakan untuk menyajikan gambaran yang hidup dalam pikiran pembaca melebihi kata-kata yang lain. Kata manusia merupakan objek yang bisa di amati oleh pancaindra manusia. Penggunaan diksi ini akan memberikan informasi dengan tepat sehingga tidak menimbulkan kesalahpahaman terhadap mitra tutur.

\section{Pembahasan Gaya Bahasa}

Analisis penggunaan gaya bahasa ini secara keseluruhan dapat di pahami bahwa di dalam wacana debat politik pilpres 2019 putaran kedua menggunakan gaya bahasa untuk membuat ide-ide yang abstrak menjadi lebih mudah diterima. Nurhikma, dkk (2019) menyatakan bahwa gaya bahasa merupakan bentuk retorik, yaitu penggunaan kata-kata dalam berbicara dan menulis untuk meyakinkan atau memengaruhi penyimak dan pembaca. Hal ini diperkuat dengan penyataan Febriani (2019) yang menyatakan gaya bahasa berbeda dengan majas. Majas hanyalah bagian kecil dari gaya bahasa, ruang lingkup gaya bahasa lebih luas dari majas dan seakan memiliki ruang lingkup yang sama bahwa majas adalah gaya bahasa dan gaya bahasa itu adalah majas. Selain itu, penggunaan gaya bahasa ini juga berfungsi untuk menghubungkan apa yang disampaikan penutur dengan pengalaman sehari-hari yang punya makna emosional yang besar bagi pendengar. Analisis penggunaan gaya bahasa ini dipaparkan sebagai berikut.

\section{Majas berdasarkan Persamaan Makna}

\section{Prabowo: "Kami yakin Indonesia bisa berdiri di atas kaki kita sendiri." (PS1)}

Pada data PS1 terdapat penggunaan majas pada kalimat "Indonesia bisa berdiri di atas kaki kita sendiri". Kalimat ini mengandung majas pleonasme (pengulangan sebagian). Pleonasme adalah pengulangan dengan penanda yang berbeda. Sebenarnya komponen makna yang ada pada kata pertama telah hadir pada wilayah makna kata berikutnya. Hal ini sependapat dengan penelitian Pangesti, dkk (2015) dalam kalimatnya yang menyatakan "Bersediakah saudara saat ini diperiksa untuk memberikan keterangan dengan sebenar-benarnya?" Frasa keterangan dengan sebenar-benarnya termasuk gaya bahasa pleonasme pada kata sebenar-benarnya. Kata sebenar-benarnya berasal dari kata benar yang berkategori nomina. Berdasarkan asal kata yang berkategori nomina, kata 
keterangan dengan sebenar-benarnya dapat diganti dengan kata keterangan dengan benar. Sejalan dengan hal tersebut Subahnan (2016:88) menyatakan gaya bahasa pleonasme digunakan dengan menambahkan keterangan pada pernyataan yang sudah jelas atau menambahkan keterangan yang tidak dibutuhkan. Hasil penelitiannya menunjukkan gaya bahasa pleonasme wacana kampanye pemilu presiden Indonesia 2014 mengandung muatan politis tertentu, yaitu terdapat upaya mengonkretkan yang abstrak, dan untuk menguatkan pesan ideologi yang mengacu kepada capres-cawapres atau pasangan capres-cawapres tertentu. Pembuat wacana mendayagunakan gaya bahasa pleonasme dengan maksud memberikan citra positif terhadap visi, misi, dan program yang ditawarkan. Menurut Saida (2012:8) menyatakan bahwa penggunaan majas pleonasme tersebut dimanfaatkan untuk menekankan sesuatu dalam kalimat yang tentunya tidak menyampingkan makna yang ingin dicapai. Dalam wilayah makna kata "berdiri" telah ada komponen makna yang terkandung dalam frasa preposisional yang muncul kemudian, yaitu, 'di', 'atas', 'kaki', dan 'sendiri'. Hal ini dikarenakan tidak mungkin berdiri dengan menggunakan kaki orang lain.

\section{Prabowo: "Kita akan menjaga pundi-pundi bangsa Indonesia supaya kekayaan kita tidak mengalir ke luar negeri." (PS2)}

Pada data PS2 terdapat penggunaan majas repetisi pada kata "pundi-pundi". Repetisi adalah perulangan bunyi, suku kata, kata atau bagian kalimat yang dianggap penting untuk memberi tekanan dalam sebuah konteks yang sesuai. Repetisi kata yang berbeda bergantung pada siapa yang mengulangi dan apa yang diulangi (Murtafi, dkk. 2017:5). Penelitian serupa mengenai gaya bahasa repetisi ditemukan dalam penelitian Subahnan (2016:87) yang menyatakan repetisi digunakan dengan mengulang bunyi, suku kata, kata, atau bagian kalimat yang dianggap penting untuk memberikan tekanan dalam sebuah konteks yang sesuai. Penggunaan gaya bahasa repetisi dalam wacana kampanye pemilu presiden Indonesia tahun 2014 mengandung muatan politis tertentu, yaitu terdapat upaya mengonkretkan yang abstrak, untuk menguatkan pesan ideologi, dan meyakinkan massa pemilih. Pembuat wacana mendayagunakan gaya bahasa repetisi dengan maksud membantah isu-isu negatif terhadap pembuat wacana ini, rakyat atau massa pemilih berperilaku sesuai dengan sikap yang ditawarkan pembuat wacana, dan menentukan pilihannya kepada pembuat wacana Kata ini mengandung pengulangan makna secara keseluruhan (repetisi). Dalam repetisi seluruh kata diulang. Pengulangan ini bisa berupa satu kata saja, berupa satu frasa, satu klausa, bahkan satu kalimat. Kata yang sama mengandung makna dan acuan yang sama pula. Kata "pundi-pundi" termasuk repetisi karena mengandung makna yang sama, yaitu asset-aset negara.

\section{Majas berdasarkan Oposisi Makna}

Prabowo: "Banyak infrastruktur yang dikerjakan dilaksanakan dengan grusak grusuk tanpa feasibilities study." (PS3)

Pada data PS3 terdapat penggunaan majas pada kata "grasak grusuk". Kata ini mengandung majas paradoks. Majas paradoks adalah opini atau argument yang berlawanan dengan pendapat umum. Seringkali di balik gagasan yang mengherankan, 
paradoks menyembunyikan kebenaran yang dapat dipertahankan. Kata grusak grusuk merupakan kata yang berasal dari bahasa Jawa yang artinya adalah buru-buru atau tergesa-gesa. Kata grusak grusuk pada data di atas dalam majas termasuk majas paradoks, yaitu majas yang merupakan ungkapan membandingkan situasi asli atau fakta dengan situasi yang berkebalikan. Penggunaan kata tersebut untuk membandingkan pekerjaan infrastuktur yang dinilai terlalu cepat padahal pada kenyataannya di lapangan, pekerjaan infrastuktur tersebut dilakukan dalam kurun waktu empat tahun. Menurut Susilowati (2016) paradoks adalah gaya bahasa yang mengandung pertentangan yang nyata dengan fakta-fakta yang ada. Misalnya pada kalimat, Bapak kelihatan terpukul, namun masih menyuguhkan senyuman penuh kasih. Kalimat Bapak kelihatan terpukul, namun masih menyuguhkan senyuman penuh kasih mengandung gaya bahasa paradoks. Dalam kalimat ini, terdapat pertentangan antara konstruksi Bapak kelihatan terpukul dan konstruksi namun masih menyuguhkan senyuman penuh kasih. Meskipun kedua konstruksi itu saling bertentangan, tetapi mengandung kebenaran karena disaat Bapak Rini merasa sedih karena peristiwa pemerkosaan yang dialami anaknya, ia juga harus tersenyum dan tegar menghibur anaknya agar tidak terlarut dalam kesedihannya.

\section{Majas Penegasan Pertentangan}

Jokowi: "Karena apa tidak ada ganti rugi yang ada ganti untung." (JW5)

Pada data JW5 terdapat penggunaan majas antitesis pada kata "ganti rugi/ganti untung". Antitesis merupakan gaya bahasa yang mengadakan komparasi atau perbandingan antara dua antonim yaitu kata-kata yang mengandung ciri-ciri semantik yang bertentangan (Susilowati, 2016:8). Hal ini juga sependapat dengan Sarifudin (2019) gaya bahasa antitesis adalah gaya bahasa yang mengandung gagasan yang bertentangan, dengan menggunakan kata-kata atau kelompok kata yang berlawanan. Kata "ganti rugi/ganti untung" mengandung majas antitesis karena merupakan ungkapan majas yang memadukan pasangan kata yang memiliki arti bertentangan (Ganti rugi/ganti untung). Seperti pada kalimat yang disampaikan oleh Joko Widodo "Karena apa tidak ada ganti rugi yang ada ganti untung." Pada kalimat tersebut mengandung makna bahwasannya kata ganti rugi memiliki padanan yang bertentangan atau berkebalikan, sehingga dimaknai dengan kata ganti untung. Karena lawan kata dari rugi adalah untung.

\section{Majas Sindiran}

Prabowo: "Di banyak tempat selama puluhan tahun perusahaan-perusahaan besar justru melanggar meninggalkan limbah tidak mau bayar pajak yang sebenarnya untuk bersihkan limbah dan kongkalikong patgulipat dengan pejabat-pejabat." (PS6)

Pada data PS6 terdapat kata "kongkalikong" dan "patgulipat". Kedua kata tersebut termasuk dalam majas ironi. Sejalan dengan hal tersebut Subahnan (2016:88) ironi digunakan untuk mengungkapkan kebahasaan yang mengatakan makna yang bertentangan dengan maksud berolok-olok. Kata-kata yang dipakai berlawanan dengan maksud sebenarnya. Berdasarkan hasil penelitian yang dilakukannya pada wacana kampanye pemilu presiden, ironi dugunakan dengan maksud berlainan dari apa yang 
terkandung dalam rangkaian kata-katanya. Gaya bahasa ironi digunakan sebagai upaya literer yang efektif karena menyampaikan kesan yang mengandung pengekangan yang besar, baik disengaja atau tidak, rangkaian katakata yang didayagunakan itu mengingkari maksud yang sebenarnya. Penggunaan gaya bahasa ironi dalam wacana kampanye pemilu presiden Indonesia tahun 2014 mengandung muatan politis tertentu, yaitu terdapat upaya membantah kampanye hitam, mengkritik kebijakan, mengancam lawan, berdiplomasi, berpropaganda, dan mengejek pihak lain. Untuk itu dapat disimpulkan majas yang menggunakan kata-kata bertentangan dengan fakta yang ada dengan maksud menyindir. Jadi, seperti memuji di awal, tapi menunjukkan maksud sebenarnya (yakni menyindir) di akhir kalimat. Hal ini dapat dilihat pada kalimat yang disampaikan oleh Prabowo Subianto dalam pernyataannya berikut ini "Di banyak tempat selama puluhan tahun perusahaanperusahaan besar justru melanggar meninggalkan limbah tidak mau bayar pajak yang sebenarnya untuk bersihkan limbah dan kongkalikong patgulipat dengan pejabat-pejabat." Pernyataan tersebut dapat dideskripsikan pada kalimat awal, yaitu banyak tempat selama puluhan tahun perusahaan-perusahaan besar, yang bermakna pak probowo memuji kehebatan adanya beberapa perusahaan besar yang selanjutnya diikuti dengan pernyataan menyindir secara langsung bahwa seperti berikut, besar justru melanggar meninggalkan limbah tidak mau bayar pajak yang sebenarnya untuk bersihkan limbah dan kongkalikong patgulipat dengan pejabat-pejabat. Pernyataan ini bertujuan untuk memuji dan sekaligus juga menyindir kinerja lawan debat. Sutianto (2013) menyatakan bahwa ironi selalu terdiri dari unsur pragmatik khusus, yaitu mengujarkan sesuatu dengan ironis selalu kurang lebih ditujukan pada sasaran bulan-bulanan. Ironi sering kali digunakan untuk mengolok dan menyampaikan sesuatu dengan ironis adalah menggunakan kosakata yang sekan-akan meninggikan nilai padahal merendahkan. Selain perubahan pertanda, dalam ironi juga ada perubahan acuan. Hal ini sejalan dengan Ibrahim (2015:52) dalam analisis data penelitiannya berupa kalimat May tertawa. "tepat, kau sungguh suami yang cerdas. Lain kali, lebih berhati-hatilah". Gaya bahasa ironi pada data di atas terdapat pada ungkapan "kau sungguh suami yang cerdas."Lain kali, lebih berhati-hatilah." Pada pernyataan tersebut mempunyai maksud yang berbeda, kata cerdas maksudnya bodoh karena akibat keterlambatan Baron bangun pagi ia menjadi tergesa-gesa berangkat ke kantor bahkan ponselnya jatuh di lift. Sindiran halus itu diungkapkan May yang ditujukan kepada suaminya agar suaminya bisa bangun lebih pagi supaya tidak keberu-buru ke kantor.

Prabowo: "Kemudian juga izin-izin akan kita perketat, amdal harus dilaksanakan tidak ada jalan-jalan pintas untuk amdal yang sangat cepat sering secara legal ada tadi, tapi kadang kadang itu etok-etok." (PS7)

Pada data PS7 terdapat kata "etok-etok". Kata tersebut merupakan kata serapan dari bahasa Jawa yang artinya adalah berpura-pura. Kata tersebut termasuk dalam majas sinisme. Majas Sinisme merupakan gaya bahasa yang menyampaikan sindiran secara langsung pada hal yang disindir. Sinisme tidak menggunakan ungkapan untuk memperhalus sindiran seperti ironi, namun sindiran juga tidak disampaikan secara kasar. Penggunaan dua kata tersebut disampaikan dalam pernyataan debat yang disampaikan oleh Prabowo Subianto. Hal itu dilakukan untuk menyampaikan pendapatnya dan sindirannya terkait kinerja pemerintah yang kurang maksimal dan dianggap hanya 
berpura-pura saja. Menurut Susilowati (2016) dalam analisis kalimat "Ingat keahliannya membuka kunci kamar Santi dan Sinta. Aneh rasanya gadis sealim dia itu tahu hal-hal begitu." Pemanfaatan gaya bahasa sinisme terdapat pada kalimat tersebut karena menggunakan kata-kata yang mengandung sindiran yang berbentuk kesangsian yang mengandung ejekan terhadap keikhlasan dan ketulusan hati. berdasarkan konteksnya. Kalimat Aneh rasanya gadis sealim dia itu, tahu hal-hal begitu, menyatakan tentang keraguan melihat keahlian membuka kunci Santi dan Sinta. Keahlian mereka seperti keahlian seorang pencuri yang ingin merampok di rumah orang dengan membobol pintu rumah menggunakan kawat, agar pintu mudah terbuka. Padahal, Santi dan Sinta terlihat polos dan alim, tetapi tahu cara membobol pintu. Hal ini juga sependapat dengan Febriani (2019) dalam penelitiannya berjudul "Gaya Bahasa Retoris dan Kiasan Najwa Shihab dalam Gelar Wicara di Trans 7" gaya bahasa sinisme bertujuan untuk memberikan sindiran terhadap narasumber yang tidak ingin memberikan informasi yang penting. Gaya bahasa sinisme juga digunakan dalam tuturan Najwa Shihab yang bergaya puitik pada segmen pembuka dan segmen catatan Najwa.

\section{Majas Perbandingan}

Jokowi: "Bukan untuk yang gede gede, bukan untuk yang gede gede." (JW8)

Pada data JW8 terdapat kata "gede-gede". Kata tersebut merupakan kata yang termasuk dalam majas asosiasi. Majas asosiasi merupakan majas perbandingan yang menonjolkan perbandingan kata yang mengutarakan suastu gagasan atau ide. Gaya bahasa asosiasi digunakan dengan membandingkan suatu benda dengan capres, cawapres, atau pasangan capres dan cawapres tertentu atau gaya bahasa yang membandingkan suatu keadaan dengan capres dan cawapres atau pasangan capres dan cawapres tertentu yang sesuai dengan keadaan yang dilukiskannya. Perbandingan itu menimbulkan asosiasi terhadap capres-cawapres atau pasangan capres-cawapres tertentu, sehingga gambaran capres-cawapres atau pasangan capres-cawapres tertentu yang disebutkan itu menjadi lebih jelas (Subahnan, 2016: 86). Majas asosiasi ini menggunakan perumpamaan atau peribahasa dalam perbandingannya. Dalam tuturan kalimat yang disampaikan oleh Joko Widodo ini menunjukkan bahwa kata "gede-gede" merujuk kepada status sosial dan para penguasa atau para petinggi yang berkuasa. Hal ini sejalan dengan penelitian yang dilakukan oleh Lestari dan Eli (2018:7) dalam data kalimat "Statsiun Cianjur tampak seperti lautan manusia, Kamis pagi 21 desember 2017. Antrean manusia mengular dari loket hingga ke area parkir." Penulis mengasosiasikan bahwa statsin Cianjur sangat dipenuhi oleh para penumpang kereta api, sehingga antreannya seperti ular yang panjang sudah tidak tertampung di dalam.

Jokowi: "Memang tidak mungkin kita membalikkan tangan dalam sehari dua hari atau setahun dua tahun, memerlukan sebuah waktu panjang untuk melakukan itu." (JW9)

Data pada JW9 terdapat kata "membalikkan tangan" yang termasuk ke dalam majas perumpamaan. Menurut Lestari dan Eli (2018:4) perumpamaan adalah padan kata simile dalam bahasa inggris. Kata simile berasal dari bahasa latin yang bermakna "seperti". 
Perumpamaan adalah perbandingan dua hal yang pada hakikatnya berlainan dan yang sengaja kita anggap sama. Dalam pernyataan kata "membalikkan tangan" tersebut, dikatakan bahwa Joko Widodo menyampaikan pekerjaan yang dilakukan pemerintah tidaklah mudah dan tidaklah langsung jadi, tetapi memudahkan beberapa waktu bahkan bertahun-tahun untuk menyelesaikannya.

Jokowi: "Kita ini manusia biasa, ada yang sudah kita kerjakan ada juga belum kita ke kerjakan karena negara ini dan negara besar bukan negara kecil." (JW10)

Data pada JW10 terdapat kata "Manusia Biasa" yang merupakan bagian dari majas litotes. Majas Lilotes merupakan ungkapan yang lebih sempit dan bertujuan untuk merendahkan diri, dan pada kenyataannya yang di maksud tidak seperti yang dikatakan. Menurut Meliala (2018:6) menyatakan bahwa gaya bahasa litotes dipakai untuk melukiskan hal sekecil-kecilnya untuk merendahkan diri. Sejalan dengan hal tersebut Budiarti, dkk. (2016:5) menyampaikan litotes adalah gaya bahasa yang mengungkapkan pernyataan dengan cara menyangkal atau mengingkari kebalikannya. Gaya bahasa litotes bisa ditandai dengan adanya kata bukanlah, bukan berarti dan hanyalah. Pernyataan kata tersebut disampaikan oleh Joko Widodo dalam debatnya dan dalam bentuk kalimat seperti ini "Kita ini manusia biasa, ada yang sudah kita kerjakan ada juga belum kita ke kerjakan karena negara ini dan negara besar bukan negara kecil." Dari pernyataan tersebut dapat disimpulkan bahwa yang disampaikan oleh bapak Joko Widodo adalah bentuk dari sikap rendah diri namun tetap pada keyakinannya bahwa nanti masyarakat Indonesia mampu mengerjakan segala aspek pemerintahan dengan maksimal. Dari pernyataan tersebut juga disampaikan kepada para pendukung untuk optimis dan sebagai upaya sugesti.

\section{SIMPULAN}

Penggunaan diksi dalam debat pilpres 2019 berdasarkan ketepatan hasil pilihan kata atau diksi yang ditemukan, yaitu pemakaian kata pengindraan, pemakaian kata khusus, pemakaian kata istilah asing, pemakaian kata antonim atau lawan kata, pemakaian kata sinonim atau persamaan kata pemakaian diksi kedaerahan, diksi konotatif, dan diksi konkret. Penggunaan gaya bahasa yang terdapat dalam debat pilpres 2019 adalah gaya bahasa yang berdasarkan persamaan makna berupa pleonasme dan repetisi, berdasarkan oposisi makna berupa majas paradoks, dan penggunaan gaya bahasa penegasan pertentangan berupa antithesis. Kemudian penggunaan gaya bahasa yang lebih dominan dalam pelaksanaan debat pilpres 2019 adalah pemakaian gaya bahasa sindiran berupa ironi dan sinisme dan gaya bahasa perbandingan berupa asosiasi, perumpamaan dan litotes.

Penelitian mengenai diksi ini dan gaya bahasa ini diharapkan dapat dijadikan sebagai acuan bagi orang-orang terutama bagi yang akan berdebat dalam tema apapun. Kemudian sebagai landasan untuk lebih baik dalam mengolah kata-kata dalam berdebat berdasarkan diksi dan gaya bahasanya. Selain itu, penelitian ini juga berguna bagi guru, dosen, mahasiswa, serta pembuatan bahan ajar. Hasil temuan ini diharapkan dapat digunakan pada kegiatan belajar di sebuah lembaga pendidikan. 


\section{DAFTAR PUSTAKA}

Agustin, D.N. (ed). (2008). Penelitian Diksi dan Gaya Bahasa dalam Pidato Presiden Soeharto. Malang: UM Press.

Budiarti,dkk. (2016). Analisis Diksi dan Gaya Bahasa pada Akun Yang Terdalam Di Media Sosial Instagram. PUBLIKA BUDAYA. Volume 1 (1) September 2016. 1-7.

Febriani, S. \& Emidar (2019) Gaya Bahasa Retoris dan Kiasan Najwa Shihab dalam Gelar Wicara Mata Najwa di Trans 7. Jurnal Pendidikan Bahasa Dan Sastra Indonesia, Vol. 8 No. 3, September 2019; Seri E 408-414.

Hardianto, M. dkk. (2017). Diksi Dan Gaya Bahasa Pada Naskah Pidato Presiden Soekarno. Jurnal Ilmiah : FONEMA, Vol 4 No. 2, Bulan Desember, Tahun 2017, 88-101.

Harmoko, D.D. (2014). Analisa Kesalahan Tata Bahasa Indonesia dalam Debat Calon Presiden RI 2014-2019. Jurnal WANASASTRA Vol. VI No. 1 Maret 2014.

Ibrahim,S. (2015). Analisis Gaya Bahasa dalam Kumpulan Novel Mimpi Bayang Jingga Karya Sanie B. Kuncoro. Jurnal Sasindo Unpam, Volume 3, Nomor 3, Desember 2015, 35-57.

Keraf, G. (2010). Diksi dan Gaya Bahasa. Jakarta: Gramedia Pustaka Utama.

Latifah,dkk. (2016). Penggunaan Diksi dalam Karangan Berita Siswa Sekolah Menengah Pertama. BASASTRA Jurnal Penelitian Bahasa, Sastra Indonesia dan Pengajarannya Volume 4 Nomor 1, April 2016, ISSN I2302-6405, 84-101.

Lestari, R.D.\& Eli, S.A. (2018). Penggunaan Gaya Bahasa Perbandingan pada Kumpulan Cerpen Mahasiswa. Jurnal Semantik, Volume 7, No. 1, Februari 2018 pp XX-XX, 1-11.

Mahsun. 2013. Metode Penelitian Bahasa Tahapan Strategi, Metode, dan Tekniknya. Jakarta: PT Raja Grafindo Persada.

Meliala, W.S. (2018). "Analisis Diksi, Gaya Bahasa, dan Citraan dalam Empat Cerita Anak Indonesia Karya Murti Bunanta". Jurnal Pendidikan Bahasa dan Sastra. Volume 18, Nomor 1, April 2018, pp, 95-105.

Moleong, Lexy J. 2014. Metodologi Peneitian Kualitatif. Bandung: PT Remaja Rosdakarya.Bandung.

Muhammad. 2011. Metode Penelitian Bahasa. Jogjakarta: AR-RUZZ MEDIA.

Murtafi, A, dkk. (2017). The Translation Analysis Of Repetition Language Style In Novel A Thousand Splendid Suns, The Technique And Quality (Translation Study Using Stylistics Approach). Prasasti:Journal of Linguistics, Vol.2 Number 1, April 2017, 120.

Noverino, R. (2015). A Bathtub Of Popcorn: Kajian Analisis Wacana Kritis Buku Cerita Anak Dwi Bahasa. UNS Journal of Language Studies 41 Volume 04, Number 01, April 2015, 41-55. 
Nurhikma, dkk. (2019). Gaya Bahasa dalam Debat Calon presiden dan Calon Wakil Presiden Republik Indonesia pada Pemilihan Umum 2019. Jurnal Publikasi Skripsi.

Nurpadillah, V. (2017). Wacana Kepemimpinan: Analisis Makna Konotasi Dalam Teks Pidato Presiden Jokowi. Jalabahasa, Volume 13, Nomor 1 Tahun 2017, 83-92.

Pangesti, Rika, dkk. (2015). Diksi dan Gaya Bahasa dalam Berita Acara Pemeriksaan di Polres Jember. Volume 1 (1) Juni 2015 PUBLIKA BUDAYA, 1-14.

Payuyasa, I.N. Analisis Wacana Kritis Model Van Dijk dalam Program Acara Mata Najwa di Metro TV. SEGARA WIDYA Jurnal Hasil Penelitian, Volume 5, November 2017, 14-24.

Permatasari, D. H. (2019). Diksi dan Gaya Bahasa Pembawa Berita Redaksiana Trans7. Jurnal BAPALA, jurnalmahasiswa.unesa.ac.id.

Putri, R.E. (2015). KOMUNIKASI POLITIK (Model Komunikasi Politik Antar Fraksi dalam Pembentukan Norma UU Pilkada Secara Demokratis). Jurisprudence, Vol. 5 No. 1 Maret 20.

Reskian, A. (2018). Analisis Penggunaan Diksi pada Karangan Narasi Di Kelas X Ips II SMA Negeri 1 Palu. Jurnal Bahasa dan Sastra Volume 3 No 2 (2018) ISSN 2302-2043.

Saida, A. (2012). Artikel Gaya Bahasa dalam Cerita Madre Karya Dewi Lestari. Malang: UM Press.

Sarifudin, Imam. (2019). Gaya Bahasa berdasarlan Struktur kalimat pada Debat Presiden Periode II Pemilihan Umum 2019. Jurnal Publikasi Skripsi.

Setiarini,N.L.P. (2015). Dongeng "The Witches' House" dan Terjemahannya "Rumah Para Penyihir": Sebuah Analisis Wacana Kritis. UNS Journal of Language Studies Volume 04, Number 01, APRIL 2015, 28-40.

Suryawan, E.W. (2013). Analisis Diksi dan Gaya Bahasa pada Novel 5 cm Karya Donny Dhirgantoro. Jurnal Publikasi Skripsi, 14halaman.

Susilowati, E. (2017). Gaya Bahasa dalam Novel Pesantren Impian Karya Asma Nadia". Jurnal Bastra (Bahasa dan Sastra). Jurnal Bastra Vol. 1 No. 2, Juli 2016.

Sutianto, A.,A. (2013). Pemakaian Gaya Bahasa Ironi dalam Tuturan Acara Sentilan Sentilun Episode Dewan Gadungan dan Pimpinan Teladan. Jurnal Publikasi Skripsi.

Subahnan. (2016). Pendayagunaan Gaya Bahasa Dalam Wacana Kampanye. WACANA: Jurnal Bahasa, Seni, dan Pengajaran. Oktober 2016, Volume 1, Nomor 1. 82-94.

Tarigan, Henry Guntur. 2009. Pengajaran Gaya Bahasa. Bandung: Angkasa.

Wibowo, A.P. (2015). Kajian Analisis Wacana Kritis pada Cerita Bergambar Anak Dwi Bahasa Kura-Kura Si Penjaga Samudra (Turtle The Guard Of The Ocean). UNS Journal of Language Studies, Volume 04, Number 01, April 2015, 1-18.

Wilianti, dkk. (2018). Analisis Diksi Puisi Wajah Negeri Kita Karya M. Anwar M.H. Jurnal Ilmu Budaya Vol. 2, No. 3, Juni 2018 e-ISSN 2549-7715, 286-292. 
Zaimar, O.K.S. \& Ayu, B.H. (2015). Teori Wacana. Jakarta: Penaku. 